\title{
Re-conceptualizing career success: a contextual approach
}

\author{
Hugh Gunz $\cdot$ Wolfgang Mayrhofer
}

Accepted: 30 November 2010 / Published online: 6 January 2011

(C) Institut für Arbeitsmarkt- und Berufsforschung 2011

\begin{abstract}
Career success has hitherto been conceptualized in ways that make its operationalization difficult to distinguish from other properties of the person, such as job satisfaction or remuneration. We argue that this is because these conventional operationalizations neglect the "career" dimension of career success. We introduce a perspective on career studies, Social Chronology Theorizing (SCrT), which in our understanding provides a richer view of career success. It calls for contextualization, pointing to the need to understand both the structure of the social space within which careers unfold and the complexity of condition, since both change over time. SCrT suggests that the measurement of career success requires pattern and narrative analysis rather than singleindex measures.
\end{abstract}

\section{Re-Konzeptionalisierung von Karriereerfolg: ein kontext-basierter Ansatz}

Zusammenfassung Bisherige Operationalisierungen von Karriereerfolg machen es relativ schwierig, dieses Konstrukt von anderen personenbezogenen Charakteristika wie Arbeitszufriedenheit oder finanzieller Erfolg zu unterscheiden, da das ihnen zugrundeliegende Verständnis von Karriereerfolg den „Karriereaspekt“ von Karriereerfolg

\footnotetext{
H. Gunz (®)

University of Toronto, Department of Management, University of Toronto Mississauga,

3359 Mississauga Road North, Mississauga L5L 1C6, ON, Canada e-mail: hugh.gunz@utoronto.ca
}

\section{W. Mayrhofer}

WU Vienna, ivm-WU Wien,

Althanstr. 51, 1090 Vienna, Austria

e-mail: wolfgang.mayrhofer@wu.ac.at vernachlässigt. Daher schlagen wir eine Perspektive für die Karriereforschung - Social Chronology Theorizing (SCrT)

- vor, die eine umfassendere Sichtweise von Karriereerfolg erlaubt.

Sie erfordert eine Kontextualisierung und weist auf die Notwendigkeit hin, bei der Analyse von Karrieren sowohl die Struktur des sozialen Raums, in dem sich Karrieren entfalten, als auch die Komplexität der jeweiligen personenbezogenen Zustände zu verstehen, beides veränderlich über die Zeit. SCrT legt nahe, dass die Messung von Karriereerfolg Musteranalysen und narrative Analysen an Stelle von Einzelindizes erfordert.

\section{Introduction}

Career success has not proven an easy concept to pin down. Although widely written about (Gunz and Heslin 2005), attempts at defining the concept are comparatively rare. Judge and Kammeyer-Mueller (2007, p. 60), for example, define career success as "the real or perceived achievements individuals have accumulated as a result of their work experiences", an interesting development of an earlier version: "The positive psychological or work-related outcomes or achievements one has accumulated as a result of one's work experiences" (Judge et al. 1995, p. 486). Sometimes, however, the career connection is fuzzier, for example "Career success may be defined as the accomplishment of desirable work-related outcomes at any point in a person's work experiences over time" (Arthur et al. 2005, p. 179), but most commonly authors skip over the conceptual definition problem and move directly to its operationalization.

Perhaps the most widely adopted approach to defining career success is to distinguish between two aspects of, in psychological terms, the state of an individual. It has 
a strong evaluative component (Jaskolka et al. 1985; Judge et al., 1995), in the sense that it is commonly thought of as a measure of either how well people seem to others to have done in their careers (objective success), or feel about how well they have done in their careers (subjective success). The two are not particularly strongly correlated (Judge and Kammeyer-Mueller 2007). Much has been written about the subjective-objective distinction (e.g. Abele et al. 2011, in press), including the different senses in which subjectivism is used (ibid; Gunz and Heslin 2005) and the reference points used by career actors in making their assessments of subjective success (Heslin 2005). Here, however, we are concerned with an issue that is meta to the objective-subjective distinction; we are concerned, in other words, with the nature of the over-arching concept.

In much of career research, conceptualizing career success (a major outcome variable) and careers in general are theoretically not sufficiently understood. Consequently, the paper addresses conceptual issues linked to career success, hoping to contribute to a better theoretical understanding of both careers and career success. We shall argue that career success is a construct that has not been fully thought through either theoretically or in its operationalization. We discuss the implications of this, and suggest a solution.

\section{Key problems in conceptualizing career success}

We start by proposing that career success suffers from two problems which are rarely considered in writing about it, which we call the "state" problem, and the "definitional" problem. The state problem emerges from the following issue: if "career success" is a measure of the instantaneous state of a person, it is in principle indistinguishable from other measures of the state of that person at that point in time. Consider the variables typically used to measure career success (Nicholson and De Waal-Andrews 2005, pp. 140-142). Objective indicators include status and rank (hierarchical position); material success (wealth, property, earning capacity); social reputation and regard, prestige, influence; knowledge and skills; friendships, network connections; and health and well-being. Subjective indicators include pride in achievement; intrinsic job satisfaction; self-worth; commitment to work role or institution; and fulfilling relationships, moral satisfaction (ibid).

In practice, subjective satisfaction with one's career is hard to distinguish from satisfaction with the job that one is doing at present, to the extent that many studies of subjective career success use job satisfaction as a proxy for it (Heslin 2005). Similarly, it is not clear why typically used measures of objective career success such as salary and promotions are labelled "career" success (although sometimes less-limited measures are used, for example the number of promotions over the course of a career - e.g. Seibert and Kraimer (2001) - or comparisons between age and organizational level - e.g. Bass (1975); Lawrence (1984)). To put the point in a different way, how are these indicators any more measures of career success, than they are simply measures of how much someone earns, or what position he or she occupies in a hierarchy? What, in other words, dignifies them with the label "career" success? For example, suppose one observes that a particular person earns $€ 300 \mathrm{~K}$ annually. How much has one learned about that person's career success? Is s/he equally as successful, career-wise, as everyone else earning $€ 300 \mathrm{~K}$ p.a.?

By analogy, it is as if one were reporting on the success of a sailor by giving the coordinates of her boat, showing that it is at a particular point in the Adriatic. Yet any measure of the sailor's success depends on understanding that reaching that point is the outcome of a voyage, a sequence of events over time, and it is the sailor's success in undertaking that voyage that is of interest, not just the point that she has reached. Without knowing, for example, which port the boat left from, how long it has been at sea, and what the sea and weather conditions were like during the voyage, one has no information by means of which to measure the sailor's success.

The definitional problem can be illustrated by considering the following two items, which are drawn from a widely used instrument measuring subjective career success (Greenhaus et al. 1990): "I am satisfied with the success I have achieved in my career"; and "I am satisfied with the progress I have made toward meeting my overall career goals". Clearly the answers to these items bring up the state problem - whether or not the respondent can distinguish between his/her current situation and his/her career but they also depend on what "career" or "career goal" means to the respondent. How does the researcher know that the respondent shares the researcher's understanding of the terms, given the many possible meanings that are encountered both in everyday life (the world presumably inhabited by the respondent), and in the scholarly literature (the world presumably inhabited by the researcher)?

To continue with our analogy, suppose one asked the sailor how she felt about "her sailing", on a scale of $1=$ "terrible" to $7=$ "wonderful", and suppose the answer was 4 . What does this mean? If she understood "my sailing" to mean "how this particular voyage had gone", it suggests that she wasn't particularly satisfied with it. If she understood it to mean "all the sailing I've ever done", it could mean the same as the first; however, she could alternatively be saying: "this one went fine, but it really doesn't show any growth in my capacities". Even if we knew that she meant the first interpretation (this particular voyage), we have no way of telling, without asking further, whether she was referring to all of the activities involved in 
getting the boat to where it is now, or whether she had in mind specifically the physical process of sailing, as opposed to the other skills, for example of provisioning, rigging, navigation, and so forth. This is, of course a problem that is generic to rating scales; we draw attention to it here because, curiously, it has been largely overlooked hitherto in the literature on career success.

Of course, one could avoid this trap by being specific in the question: instead of asking about "her sailing", one could have asked about "the way she handled this particular voyage in its totality". But, typically, this is not done when career success is being measured, as witness the items listed above: the first item is not: "I am satisfied with the success I have achieved in my career as a public accountant, taking into account everything I do as an accountant but ignoring my life outside accountancy". It refers simply to "career", leaving it up to the respondent to interpret the term as he or she wishes.

At the root of these issues is a lack of conceptual clarity about the nature of career success. As we saw above, definitions vary from reasonably specific to rather less so, and there is surprisingly little discussion of its theoretical basis in the literature. Indeed it is common for researchers to skip over the definitional stage altogether and select an operationalization without further discussion. Sometimes it is hard to escape the conclusion that, for many authors, the operationalization is the construct. As Feldman and $\mathrm{Ng}$ (2007, p. 351) point out in a recent review, "[t]he term career success has become a catchall signifier for widely disparate measures of achievement, ranging from very specific measures of salary increases to very general measures of psychological well-being".

Next, we review briefly the many senses in which "career" is used, and suggest that a new approach to career studies, Social Chronology Theorizing, captures this complexity and provides a useful approach to framing career success as a more contextualized concept. We conclude by considering some of the theoretical and methodological implications of this approach.

\section{Social chronology theorizing and career success}

\subsection{Conceptualizations of careers}

In order to make any progress with these conundrums we need to address a more basic question: what actually is "career"? The question turns out to be more complex than at first it appears: As Hall (2002, p. 8) points out, "the term career suffers from surplus meaning"; nor is its theoretical basis at all clear (Gunz and Peiperl 2007). There is general agreement that careers have voyage-like properties, in the sense that they involve a series of experiences (for most au- thors in the behavioural literature, work-related) over time, but there is little consensus beyond that. In the scholarly literature it is used, by and large, in six different senses:

1. A pattern of roles/offices examined over time (the "objective" career; Hughes 1958, p. 63); e.g. "A career is the sequence of work-related positions occupied throughout a person's life" (London and Stumpf 1982, p. 4).

2. A pattern of roles/offices, taken together with the subjective experience of the individual, examined over time ("objective" and "subjective" career; Schein 1980, p. 357); for example "the evolving sequence of a person's work experiences over time" (Arthur et al. 1989, p. 8).

3. Career as retrospective sense-making, which Nicholson and West (1989) argue is what distinguishes it from what they describe (p. 181) as "work history".

4. Career as that which connects levels of analysis; a "moving perspective in which persons orient themselves with reference to the social order" (Hughes 1958, p. 67); career "falling at the intersection between the individual and society" (Schein 1980, p. 357).

5. Career as the product of a life's work, rather than a process, for example Bird's (1996) account of "careers as accumulations of information and knowledge embodied in skills, expertise, and relationship networks that are acquired through an evolving sequence of work experiences over time" (p. 150).

6. Career as movement through space-time: the concept of "path" or "road" is deeply embedded in "career", even linguistically (Oxford English Dictionary 1989). The "space" can be social, occupational or organizational, such that "movement is contextualized, anchored in a specific social space" (Collin 2006).

This list, of course, comes only from careers scholars; the term is used in yet more and different ways in everyday life, ranging from an occupation to a life-course.

\subsection{Social chronology theorizing}

In an effort to bring greater clarity to the definition of career success we draw on a theoretical model of career we label "Social Chronology Theorizing" (SCrT). It brings together three distinct perspectives, the conditionary, boundative and temporal (Gunz and Mayrhofer 2009). In brief, the conditionary perspective focuses on everything we know about the career actor at any given moment in time; the boundative on the structuring of the contextual constraints, enablers, and punctuators (the boundaries, Gunz et al. 2007, that shape careers); and the temporal on the time over which careers are played out. Hence, we define career as a pattern in condition over time within a bounded social space, where the 
bounded social space may be work-related if the interest is in work careers, and more broadly conceived if not.

Taken together, the three perspectives define a space within which the individual's career can be mapped. Over the course of their lives individuals' condition changes: they become older, their educational and occupational status changes; they cross boundaries of various kinds. This pattern of change in condition through a process of boundary-crossing over the course of the individual's life defines the person's career and differentiates it from those of others. Identifying these perspectives and the related constructs - condition, boundary, and time - constitutes an organizing framework that helps career researchers to address generic issues in their research. Note that SCrT itself is an organizing framework and not a full-fledged theory itself. As such, it offers a blueprint for systematically including theories from other domains of research, for example economics, psychology, sociology, and management by relating the constructs in a theoretically sound way. SCrT comes from a tradition more related to management research, i.e. primarily focusing on the issues of work careers which is a narrower subject. It also stands in the tradition of a more contextualized view on careers, emphasizing its social boundedness and the embeddedness in time, i.e. past experience, comparable to life course analysis. However, the major contribution of SCrT as an organizing framework is to provide a systematic way of linking various theoretical concepts with regard to concrete research questions whereas life course analysis is a broad paradigm subsuming a number of different approaches.

SCrT can help in designing career studies as well as better conceptualizing career success (Gunz and Mayrhofer 2009), although a full account of how this might be is beyond the scope of this article. In brief, the three perspectives constitutive of SCrT - conditionary, boundative and temporal and their mutual relationships encourage researchers to include all three aspects simultaneously in their research questions. For example, when analyzing the effects of personality on career success, measured as yearly income (a classical theme in career research), SCrT helps to systematically check for potentially interesting additional variables to include and directs researchers to theoretical discourses dealing with these variables. Both personality and yearly income are variables typically emerging when looking from a conditionary perspective. From a boundative perspective, one could think about the moderating effects of boundative variables such as changes between labour market segments, intra- vs. interorganizational changes, types of boundaries crossed (e.g. functional, organizational, hierarchical) or different kinds of career logics. From a temporal perspective, the effects of personality on monetary income not only have to be differentiated according to short-, mid- and longterm effects, but also with regard to different subjective per- ceptions of time or to culture-based concepts of time influencing the perception of success, for example within which time period a certain financial level has to be achieved.

Regarding the conceptualization of career success, SCrT also provides some additional insight. Status, rank, health, pride in achievement, intrinsic job satisfaction, self-worth, even network connections are things we know about the person, and are therefore aspects of condition. So at least at first sight it seems that success is defined by the person's condition. However, to return to our nautical analogy, there may be several sailors occupying a similar spot in the Adriatic on different boats, but if we are to compare their relative success in getting there we need to know whether they all left port at the same time, and whether it was the same port. If we are particularly interested in their capabilities we will also need to know about the challenges they faced during their respective voyages: did one hit bad weather, did another have engine trouble, and so on? In addition, where does this put the sailors in the future since their boats might differ in their capabilities to keep free from a leeward shore or tacking angles allowing them to go upwind fast?

By the same token, if we are to make a sensible comparison between two people earning $€ 300 \mathrm{~K}$ p.a. (a simple conditionary observation) we need to know how their condition has changed over time, and how their career was structured over time by boundary-crossing. If not, then we risk making a spurious comparison between, for example, on the one hand the daughter of a factory worker who has paid her way through school and university, worked her way up through a company and at the time of our study has reached a senior position, with on the other hand the son of a wealthy industrialist who has been parachuted into a senior position in his father's firm. By analogy, this is rather like comparing the success of two boats reaching a harbour upwind, one of which is a 750HP speedboat and the other is a small sailboat. Similarly, if we are to compare two people who apparently have had the same number of promotions over the course of their career (e.g. Seibert and Kraimer 2001), but we have no information about how long their career has lasted, again we risk making spurious comparisons. In other words, assessing career success must involve more than just an examination of condition; it needs to include the career context of that condition, and that context is supplied by the boundative and temporal perspectives.

Pattern analysis SCrT suggests that the key concept for defining career success is pattern analysis: an analysis of the pattern formed by a success indicator - some form of the career actor's condition - over time in a concrete social space. Next, we review what each of the three perspectives suggests for how to approach this pattern analysis.

The conditionary perspective draws attention to the importance of configuration. SCrT suggests a potentially allencompassing view when looking at career actors' condi- 
tions as "everything we know about the career actor at any given moment in time" (see above). In practice, of course, the researcher needs to be more specific: different studies will focus on different aspects of condition.

On the one hand there is a need to limit the potential breadth of the "everything we know" exhortation, for both theoretical and pragmatic reasons. Regarding the former, the relevance of specific elements of career actors' condition depends on the underlying theory being applied. If, for example, one uses Derr's career orientations (Derr 1986) or Schein's career anchors (Schein 1990) linked with humanistic psychology, constructs such as "degree of self-realization" become relevant when measuring career success; when using a more sociologically oriented concept, for example a field- and habitus-based concept of careers (Iellatchitch et al. 2003), different kinds of career capitals and their increase over time or current worth in a specific career field might take centre stage. In pragmatic terms, things like the availability of given data, the access to the target population or financial resources limiting the amount and kind of data that can be gathered and analyzed can lead to a selection of conditionary variables.

On the other hand, it is important to be not too reductionist. It is necessary to choose a sufficient variety of conditions, because the meaning of one indicator by itself is extremely limited (Arthur et al. 2005). The significance of wealth to a person, for example, varies with other aspects of condition, for example age or societal context. Earning $€ 40 \mathrm{~K}$ in marketing is of little use as an objective career success indicator if ones does not have additional information on age, career stage, and country: for a 25-year-old undergraduate in Zambia it is most likely an objective success; for a 55-year-old MBA in Paris it might be less so. Therefore, the conditionary perspective serves as a constant reminder to link career actors' career success to different configurations of success indicators.

The boundative perspective is about the individual's position with respect to (not) crossing the boundaries that derive from the social context within which the career is being made. Looking at career success without either examining the various types of boundaries crossed in the past or analyzing the constraining and enabling effects of present boundaries for the future career is blatantly incomplete. The type of boundary examined depends both on the focus of the research and on the theoretical lenses used. For example, someone with an interest in work careers makes implicit assumptions about the pre-eminence of work in a person's life that are not shared by someone with a broader definition of career. A Bourdieuian will see the social space in terms of actors and rules; a symbolic interactionist, the emergence of meaning through interaction.

Equally important are the kind of boundaries that individuals have crossed hitherto. Depending on the types of boundaries crossed, it may be hard to argue that two persons with apparently the same objective career success are "really" equally successful. For example, take two women of the same age, each with a similar job as a web designer for a high-end software company and with similar income. Woman A grew up in an orphanage and after a short jailterm for drug abuse took evening classes at an adult education centre, qualifying her for clerical work during which she detected her interest and gift for web design. This provided the basis for her current job. Woman B is the daughter of a mother who is a technical engineer with a multinational oil company and a father who is a teacher, has a bachelor's degree in engineering and took additional web-design courses at a renowned private institute. Everything else being equal, intuitively it is difficult to speak of equal success between these cases. Woman A had to cross a number of boundaries, many of which were hard to cross. In terms of professional background, her formal education was insufficient and she had to convince a potential employer that even outside the boundaries of her certified competencies she was able to do the job. The current job puts her beyond her original social context, especially in light of her track record as a convicted drug abuser. Among other things, she had to cross boundaries linked to stereotypes and prejudices, to type of language used as well as to social networks. The situation is different for Woman B. She had to cross few professional and social boundaries. Her current position is perfectly in line with her educational background. Likewise, her social status as a web designer is not inconsistent with her context of origin. Some would argue that this is like comparing apples and oranges. However, this is exactly what happens in part of career research, for example, when comparing individuals by the achieved hierarchical or income level. Unless the study does control for a number of background and historical variables, it is all too often that in a "snapshot-logic" the current situation is evaluated without taking into account the broader circumstances and the historical pattern.

Boundaries linked with a career actor's current situation are also very important because of their fundamental role in constraining and enabling future developments. As above, differing boundaries may cause seemingly identical situations in terms of career success to be not identical at all. Take, for example, the situation of two expatriate managers with similar social and educational background, experience, age and income, who are building up the local operations in Romania for their companies with headquarters in Switzerland. Assume, despite these similarities, a crucial difference in the career logics (Gunz 1988, 1989) governing this assignment. Manager A has been sent abroad under a high-flyer logic framing the assignment as a stepping stone for future promotions. Manager B is regarded as a threat for an internal competitor in the corporate headquarters and has been sent abroad under an 
"isolation" or "dead end" logic, in order to try to block his further development while keeping up surface appearances (for a more detailed view on different types of foreign assignment career logics see Mayrhofer 1996, 2001). Despite similar objective and - if both managers are unaware of these career logics - potentially subjective career success the boundative perspective enforces a differentiated view. Evaluating current career success also requires taking into account what the boundaries linked with the current position mean for the managers' next career steps. In the example, for manager $\mathrm{A}$ the current position is an asset helping her to overcome some boundaries linked with her next career step, for example becoming a country manager in an established market, by helping to reduce the gap between required and actual experience. In the case of manager $\mathrm{B}$, the current job makes the boundaries around getting a new job less permeable. The geographical distance to crucial decision-makers in headquarters and the social connotation as having fallen from grace make the next career move more difficult for him. Boundaries, therefore, provide a crucial element in analyzing career success.

The temporal perspective draws attention to the importance of sequence in a career. At the very least, the duration and order of career experiences must be taken into account when evaluating career success. If one were to examine the career track of two otherwise similar persons with identical building blocks in their careers, for example a) vocational training, b) first job as trained manual worker, c) first-line supervisor and d) middle manager, the duration of each of these career segments is crucial for evaluating each person's current career success. Sequence A with three years vocational training, two years as manual worker, two years as first-level supervisor and ten years as middle manager tells a different story from sequence B with three years vocational training, five years manual worker, eight years of first-level supervisor and one year as middle manager. Sequence A suggests normal vocational training, rapid promotion in the two subsequent hierarchical levels and current establishment in middle management. Sequence $\mathrm{B}$, however, implies normal vocational training, a delay in getting promotion to higher levels, and finally just making it into middle management where it remains to be seen whether this will work out or not.

As well as duration, the relative order of career experiences is crucial, too. The same set of experiences may mean very different things in terms of success, depending on the order in which they occur. Imagine a career consisting of one bad experience amongst several good ones. The likelihood is that the earlier this bad experience occurs in the career, the more profound its impact on subsequent developments; the later it comes, the greater the career actor's chances of having developed resiliencies to overcome its effects. Failing in one's first job and having three successful jobs af- terwards will most likely still leave the basic uncertainty of "Am I really up to this?" in an individual. Conversely, failing in one's fourth job after three successful previous assignments is more likely to lead to reactions of "Well, anybody can fail at some stage!" by the career actors and their social environment.

Operationalizing career success SCrT also raises a number of issues connected with operationalizing career success, which current views of career success tend to neglect. Since there is no finite number of potential constructs, a few examples related to the core issues may suffice. In terms of the conditionary perspective, we currently do not have any established measure that can be used in response to the call for configurational comparison. For some elements of condition, widely used measures exist in career research such as Greenhaus' measure of subjective career success (Greenhaus et al. 1990) or various measures of personality, for example the Big-Five approach (Seibert and Kraimer 2001; Judge et al. 1999). Yet, there is an urgent need to develop instruments that allow the researcher to capture configurational settings and use them in career research. From a boundative perspective, the situation seems to be even more dire. To the best of our knowledge, measures concerning the number and type of boundaries that need to be included are not used in career success research. In a similar way, other elements of the social space such as the number and type of actors, their relationships and networks, for example how one can trace the set of connections that might influence, or be influenced by, a given career actor, the density of career-related rules in a given segment of the social space, or the relationships between different segments of the social space (e.g. home and work), are not systematically covered by adequate instruments, either. Although at least some instruments exist and are used in other research areas, for example sociometric analysis or network analysis, little of it is used in career research. Finally, from a temporal perspective, issues of operationalization are largely unsolved if one thinks not only of length but also about the combination of duration and sequence (see Abbott and Hrycak 1990, for a rare exception to this observation).

Beyond objective and subjective career success In addition to drawing attention to these requirements, SCrT may also bring together subjective and objective career success in a useful way. As we noted above, they are empirically only moderately correlated, and indeed there has been much discussion on the theoretical connections between the two (e.g. Nicholson and De Waal-Andrews 2005; Arthur et al. 2005) and why the correlations may not be as high as a naive view (if I have done well in life, why should I not be happy?) might suggest (e.g. Hall and Chandler 2005). Despite this, the two constructs are typically discussed as though they are quite distinct (Judge and Kammeyer-Mueller 2007; $\mathrm{Ng}$ et al. 2005). SCrT, 
however, makes no distinction between the two: condition is, in principle, everything we can say about an individual, so it encompasses both subjective and objective descriptors. Happiness, wealth, career satisfaction, and status in its many manifestations are all aspects of condition. Let us imagine examining the objective career success of a particular person in increasing detail, that is, bringing more and more aspects of objective condition into the picture. Inevitably we shall get drawn into a view of the career that includes subjective elements. For example, the more one learns about the sequence of roles someone occupies (objective), the more one is drawn into examining the intentions of the career actor (subjective). Conversely, the more we examine the way someone's sense of self-worth or satisfaction changes over time, the more we are forced to ask: what objectively was going on at the time to explain these changes? So SCrT, by failing to differentiate in principle between the objective and subjective - in other words, by including both kinds of condition under the same conceptual roof - provides a framework for regarding the objective as context for the subjective and vice versa, an example of what Luhman calls mutual provision of meaning (in a similar way as interpenetration, Luhmann's theoretical figure related to the mutual provision of complexity of social systems; see Luhmann 1995, pp. 210 ff.).

That said, SCrT does point to a difference in approach when analyzing condition from respectively objective and subjective views. At the objective end of the scale, the pattern analysis involved depends on a quantitative study of the patterns in numerical data (e.g. Abbott 1995; arguably, hazard analysis techniques used in population ecology play a similar role in the analysis of the "careers" of organizations). At the subjective end of the scale, pattern analysis becomes much closer to narrative analysis, the study of the narratives constructed by career actors. Each approach, of course, uses very different building blocks and methodologies.

\section{Concluding remarks}

Social Chronology Theorizing directs one's attention to a very rich view of career success. It calls for contextualization: conceptualizing and measuring career success depends on understanding both the structure of the social space within which careers unfold and the complexity of condition, as both change over time. It calls for examining patterns. None of this is easy.

Obviously, it requires us to make choices, to choose particular aspects of condition, boundaries, and segments of time to focus on, in order to keep a sense of perspective. But if we concentrate only on single-index measures of success we risk construct invalidity, measuring something which simply is not career success. Measures of "career satisfaction" can only be viewed as such if the subjects in question are able to articulate their concept of "career" in a way that is comparable with that of those with whom their career success is being compared. Otherwise, we are merely looking at points of data, with no career meaning attached to them. Single-index measures also carry the risk of making spurious comparisons, of the kind we saw above when comparing the daughter of the factory worker with the equally paid son of the factory owner.

Just as the sailor's success cannot adequately be expressed in terms of where she is in the ocean, but also needs the subjectively recreated and objectively mapped story of how she got there, career success cannot be adequately expressed in terms of a person's condition at a particular point in time. It also needs the subjectively created and objectively mapped story of his/her career up to that point in time.

SCrT, then, offers a definition of career success as an evaluative statement about the condition of an individual at a particular point in time, viewed in the context of the pattern of condition over the course of that individual's career, within the bounded social space that has enclosed the career. This is tacitly acknowledged in studies of careers success in which many aspects of each subject's career are controlled for (for example age, number of positions occupied, profession, education). However, controlling for variables excludes them from understanding, in the sense that the more closely controlled a study, the narrower the understanding that emerges (Thorngate 1976).

Clearly, one challenge for SCrT is that it cuts across a broad range of different understandings of career. When applied to the design of a concrete empirical study, SCrT has to take into account the respective core metaphors and basic assumptions. However, at the conceptual level SCrT as an organizing framework concept with its generic categories and theoretical language provides useful guidance across a number of different approaches and metaphors to careers.

In this paper we have been arguing for breadth and depth of understanding, and the approach we have suggested has, we believe, the potential to provide us with this richness. Career success is a much-studied construct; it is high time that it receives the conceptual focus that it needs.

\section{Executive summary}

Career success is an elusive concept to work with. Although it turns up regularly in research on careers as a dependent variable, there have been very few attempts at understanding quite what is meant by the term. Typically it is defined by the way in which it is operationalized, a theoretically vac- 
uous approach. It is common to distinguish between objective and subjective success, the former referring to outward manifestations of a successful career and the latter to internal feelings of success. But neither addresses two other problems.

The first, which we call the "state" problem, is that the indicators of success that are typically used are hard, if not impossible, to distinguish from indicators of, for example, job satisfaction. The second, the "definitional" problem, is that researchers rarely make an attempt to understand what the people they are studying mean when they refer to "career success". Everyone assumes that it is too obvious to need explanation, yet it can have a very wide range of meanings, both in the scholarly literature and in everyday life. This, in turn, emerges from the fact that the word "career" can have many different meanings as well.

In this paper we introduce a new approach to research on careers that we call Social Chronology Theorizing (SCrT). We suggest that the study of careers involves the simultaneous application of three perspectives that we call conditionary, boundative and temporal, the combination of these three we call SCrT. The conditionary perspective focuses on everything we know about the career actor at any given moment in time; the boundative on the structuring of the contextual constraints, enablers, and punctuators (the boundaries that shape careers); and the temporal on the time over which careers are played out. Hence, we define career as a pattern in condition over time within a bounded social space, where the bounded social space may be work-related if the interest is in work careers, and more broadly conceived if not.

SCrT provides a useful framework by means of which to conceptualize career success. First, one views the situation of a career actor in terms of his or her condition, for example in terms of status, rank, health, pride in achievement, intrinsic job satisfaction, self-worth, even network connections. Next, one specifies the boundaries crossed over the course of the actor's career to date, because that provides the context that is needed in order to interpret the meaning of the aspects of condition that are being measured. Without this historical context it is impossible to make meaningful comparisons between, for example, two individuals each earning the same salary. Each, after all, may have arrived at this particular point via entirely different routes. Finally, the temporal perspective is needed for similar reasons: the speed with which an individual has arrived at a particular situation with given status, rewards and so on - or the age at which he or she has done so - is a critical indicator of his or her career success.

The essence of applying SCrT to career success is that it involves pattern analysis. If career is a pattern in condition over time, then success is a particular aspect of that pattern. This, in turn, presents the career scholar with the challenge of discovering tools for measuring these patterns. In the paper we discuss some of the crucial features required of such a tool, in terms of the features of condition, boundary and time that become important to the assessment of career success.

We also show how SCrT provides a way of unifying objective and career success. Long regarded as two distinct constructs with low intercorrelations, we show how the more closely either one is studied, using SCrT as guide, the more the researcher finds that he or she is actually studying a phenomenon which combines aspects of both objective and subjective career. The pattern analysis involved may vary from quantitative studies of patterns in numerical data at the objective end of the scale to narrative analysis at the subjective end, but in concept the same operation is being performed in each case.

SCrT, then, directs our attention to a very rich view of career success; it calls for contextualization: conceptualizing and measuring career success depends on understanding both the structure of the social space within which careers unfold and the complexity of condition, as both change over time. It calls for examining patterns.

It requires the researcher to make choices about which aspects of condition, boundary and time to focus on, but it emphasizes the need to focus on all three. We argue, in other words, for a breadth and depth of understanding of the concept of career success that, hitherto, it has often lacked.

\section{Kurzfassung}

Karriereerfolg ist bisher ein relativ schlecht definiertes Konzept. Obwohl es regelmäßig als abhängige Variable in der Karriereforschung Verwendung findet, gab es bis jetzt nur wenige Versuche einer genauen Klärung, was damit eigentlich gemeint ist. Typischerweise wird Karriereerfolg so definiert, wie er auch operationalisiert wird - ein theoretisch eher fragwürdiger Zugang. Üblicherweise wird zwischen objektivem und subjektivem Karriereerfolg unterschieden. Ersterer bezieht sich auf sichtbare Erscheinungsformen einer erfolgreichen Karriere, letzterer auf inneres Erleben von Erfolg. Beides aber greift im Hinblick auf zwei zentrale Probleme zu kurz.

Das erste Problem - das „Zustandsproblem“- bezeichnet die Tatsache, dass Erfolgsindikatoren für Karriereerfolg typischerweise kaum von Indikatoren für andere „Zustände“ wie etwa Arbeitszufriedenheit zu unterscheiden sind. Das zweite Problem - das „Definitionsproblem“ - bezieht sich darauf, dass in der Forschung selten versucht wird genauer $\mathrm{zu}$ verstehen, was die Betroffenen selbst eigentlich unter Karriereerfolg verstehen. Es wird angenommen, dass das ohnehin klar auf der Hand liegt. Allerdings hat Karriereerfolg sowohl in der Forschung als auch in der Alltags- 
sprache eine ganze Reihe von Bedeutungen. Letztlich rührt das daher, dass „Karriere“ selbst ganz unterschiedliche Bedeutungen haben kann.

In diesem Beitrag thematisieren wir einen neuen Ansatz zur Erforschung von Karrieren unter der Bezeichnung Social Chronology Theorizing (SCrT). Wir vertreten die Ansicht, dass die Erforschung von Karriere die gleichzeitige Anwendung von drei Perspektiven - konditional, grenzbezogen und zeitlich - beinhaltet, deren Kombination wir als Social Chronology Theorizing (SCrT) bezeichnen. Die konditionale Perspektive fokussiert auf alles, was wir über einen Karriereakteur zu einem bestimmten Zeitpunkt wissen. Die grenzbezogene Perspektive konzentriert sich auf strukturierte kontextuelle Beschränkung, Ermöglichung und Interpunktion (die Grenzen, welche Karriere formen). Die zeitliche Perspektive beinhaltet die Zeit, innerhalb derer sich Karriere entfaltet. Daher definieren wir Karriere als ein Muster an Zuständen über die Zeit innerhalb eines beschränkten sozialen Raums. Der beschränkte soziale Raum ist dann arbeitsbezogen, wenn das Interesse der Arbeit gilt, kann aber auch darüber hinaus gehen.

SCrT stellt einen hilfreichen Rahmen für die Konzeptualisierung von Karriereerfolg dar. Erstens wird die Situation eines Karriereakteurs im Lichte des jeweiligen Zustands gesehen, also z. B. im Hinblick auf Status, Rang, Gesundheit, Stolz auf die Leistung, intrinsische Arbeitszufriedenheit, Selbstwert oder sogar Vernetzung. Zweitens spezifiziert dieser Rahmen die bisherigen Grenzüberschreitungen im Rahmen der Karriere. Das ist erforderlich, um den Kontext zu benennen, den es für eine adäquate Interpretation der jeweils gemessenen Zustände braucht. Ohne den historischen Kontext ist es unmöglich, sinnvolle Vergleiche zwischen Individuen - z. B. hinsichtlich ihres Gehalts - zu machen, die z. B. auf sehr unterschiedlichen Routen zum gegenwärtigen Zustand gekommen sein können. Drittens braucht es die zeitliche Perspektive aus ähnlichen Gründen. Die Geschwindigkeit, mit der ein Individuum eine bestimmte Situation mit einem spezifischen Status, entsprechende Belohnungen erreicht hat und auch in welchem Alter das passiert ist, stellt einen wichtigen Indikator für den jeweiligen Karriereerfolg dar.

Zentral für die Anwendung von SCrT auf Karriereerfolg ist Musteranalyse. Wenn eine Karriere ein Muster an Zuständen über die Zeit ist, dann ist Erfolg ein bestimmter Aspekt dieses Musters. Das wiederum stellt die Karriereforschung vor die Aufgabe, Tools zum Herausfiltern solcher Muster bereitzustellen. Dieser Beitrag diskutiert wesentliche Merkmale solcher Tools im Hinblick auf Zustand, Grenzen und Zeit zur Bestimmung von Karriereerfolg.

Der Beitrag zeigt auch eine Möglichkeit zur integrativen Betrachtung von objektivem und subjektivem Karriereerfolg. Üblicherweise als zwei getrennte Konstrukte mit mäßigem Zusammenhang betrachtet, weist der Beitrag darauf hin, dass eine genauere Analyse von Karriereerfolg ein Phänomen analysiert, das sowohl objektive als auch subjektive Aspekte vereinigt. Die erforderliche Musteranalyse kann sowohl quantitative Analysen von Mustern in Zahlenreihen am „objektive“ Ende des Spektrums als auch narrative Analysen am ,subjektiven“ Ende beinhalten. Konzeptionell erfordert beides eine idente Operation.

Damit richtet SCrT das Augenmerk auf einen sehr reichhaltigen Blick auf Karriereerfolg. Dieser erfordert Kontextualisierung: die Konzeptualisierung und das Messen von Karriereerfolg hängt vom Verstehen der Strukturen des sozialen Raums, in dem sich Karrieren entfalten, ab und von den komplexen Geflecht von Zuständen - und beides verändert sich über die Zeit. Daher ist eine Analyse von Mustern erforderlich.

Karriereforschung im Rahmen von SCrT erfordert daher Wahlentscheidungen darüber, welche Aspekte von Zustand, Grenze und Zeit fokussiert wird, betont aber gleichzeitig die Wichtigkeit aller drei Dimensionen. Im Kern argumentiert der Beitrag daher für ein weites und tiefes Verständnis von Karriereerfolg, das in bisherigen Forschungsbemühungen oft fehlt.

\section{References}

Abbott, A.: Sequence analysis: new methods for old ideas. Annu. Rev. Sociol. 21, 93-113 (1995)

Abbott, A., Hrycak, A.: Measuring resemblance in sequence data: an optimal matching analysis of musicians' careers. Am. J. Sociol. 96(1), 144-185 (1990)

Abele, A.E., Spurk, D., Volmer, J.: The construct of career success: measurement issues and an empirical example. ZAF, this issue (2011) (in press)

Arthur, M.B., Hall, D.T., Lawrence, B.S.: Generating new directions in career theory: the case for a transdisciplinary approach. In: Arthur, M.B., Hall, D.T., Lawrence, B.S. (eds.) Handbook of Career Theory, pp. 7-25. Cambridge University Press, Cambridge (1989)

Arthur, M.B., Khapova, S.N., Wilderom, C.P.: Career success in a boundaryless career world. J. Organ. Behav. 26(2), 177-202 (2005)

Bass, B.M.: European and American managers life goals and career success. IRGOM Technical Report 74-2 (1975)

Bird, A.: Careers as repositories of knowledge: considerations for boundaryless careers. In: Arthur, M.B., Rousseau, D.M. (eds.) The Boundaryless Career: a New Employment Principle for a New Organizational Era, pp. 150-168. Oxford University Press, Oxford (1996)

Collin, A.: Career. In: Greenhaus, J.H., Callanan, G.A. (eds.) Encyclopedia of Career Development, pp. 60-63. Sage Publications Inc., Thousand Oaks, CA (2006)

Derr, C.B.: Managing the New Careerists: the Diverse Career Success Orientations of Today's Workers. Jossey-Bass, San Francisco (1986)

Feldman, D.C., Ng, T.W.H.: Careers: mobility, embeddedness and success. J. Manag. 33(3), 350-377 (2007)

Greenhaus, J.H., Parasuraman, S., Wormley, W.: Effects of race on organizational experiences, job performance evaluations, and career outcomes. Acad. Manag. J. 33(1), 64-86 (1990) 
Gunz, H.: Organizational logics of managerial careers. Organ. Stud. 9, 529-554 (1988)

Gunz, H.: Careers and Corporate Cultures. Managerial Mobility in Large Corporations. Basil, Blackwell, Oxford (1989)

Gunz, H.P., Heslin, P.A.: Reconceptualizing career success: introduction to a special issue of the Journal of Organizational Behavior. J. Organ. Behav. 26(2), 105-111 (2005)

Gunz, H., Mayrhofer, W.: Towards organizing career studies: condition, boundary and time. Paper presented at the Annual Colloquium of the European Group for Organizational Studies, Barcelona (2009)

Gunz, H., Peiperl, M.: Introduction. In: Gunz, H., Peiperl, M. (eds.) Handbook of Career Studies, pp. 1-10. Sage Publications, Thousand Oaks, CA (2007)

Gunz, H., Peiperl, M., Tzabbar, D.: Boundaries in the study of career. In: Gunz, H., Peiperl, M. (eds.) Handbook of Career Studies, pp. 471-494. Sage Publications, Thousand Oaks, CA (2007)

Hall, D.T.: Careers in and out of Organizations. Sage Publications, Thousand Oaks, CA (2002)

Hall, D.T., Chandler, D.E.: Psychological success: when the career is a calling. J. Organ. Behav. 26(2), 155-176 (2005)

Heslin, P.A.: Conceptualizing and evaluating career success. J. Organ. Behav. 26(2), 113-136 (2005)

Hughes, E.C.: Men and Their Work. The Free Press, Glencoe, Ill (1958)

Iellatchitch, A., Mayrhofer, W., Meyer, M.: Career fields: a small step towards a grand career theory? Int. J. Hum. Resour. Manag. 14, 728-750 (2003)

Jaskolka, G., Beyer, J.M., Trice, H.M.: Measuring and predicting managerial success. J. Vocat. Behav. 26(2), 189-205 (1985)

Judge, T.A., Kammeyer-Mueller, J.D.: Personality and career success. In: Gunz, H., Peiperl, M. (eds.) Handbook of Career Studies, pp. 59-78. Sage Publications, Thousand Oaks, CA (2007)

Judge, T.A., Cable, D.M., Boudreau, J.W., Bretz, R.D.: An empirical investigation of the predictors of executive career success. Pers. Psychol. 48(3), 485-519 (1995)

Judge, T.A., Higgins, C.A., Thoresen, C.J., Barrick, M.R.: The big five personality traits, general mental ability, and career success across the life span. Pers. Psychol. 52, 621-652 (1999)

Lawrence, B.S.: Age grading: the implicit organizational timetable. J. Occup. Behav. 5, 23-35 (1984)

London, M., Stumpf, S.A.: Managing careers. Addison-Wesley, Reading, MA (1982)

Luhmann, N.: Social Systems. Stanford University Press, Stanford (1995)

Mayrhofer, W.: Mobilität und Steuerung in international tätigen Unternehmen. Eine theoretische Analyse. Schäffer-Poeschel, Stuttgart (1996)

Mayrhofer, W.: Organisational international career logics (OICLs). A conceptual tool for analysing organisational expatriation pat- terns and their consequences for the management of organisations. Thunderbird Int. Bus. Rev. 43, 121-144 (2001)

Ng, T.W.H., Eby, L.T., Sorensen, K.L., Feldman, D.C.: Predictors of objective and subjective career success: a meta-analysis. Pers. Psychol. 58(2), 367-408 (2005)

Nicholson, N., De Waal-Andrews, W.: Playing to win: biological imperatives, self-regulation, and trade-offs in the game of career success. J. Organ. Behav. 26(2), 137-154 (2005)

Nicholson, N., West, M.: Transitions, work histories and careers. In: Arthur, M.B., Hall, D.T., Lawrence, B.S. (eds.) Handbook of career theory, pp. 181-201. Cambridge University Press, Cambridge, England (1989)

Oxford English Dictionary: 2nd edn. Oxford University Press, Oxford (1989)

Schein, E.H.: Career theory and research: some issues for the future. In: Derr, C.B. (ed.) Work, family, and the career: new frontiers in theory and research, pp. 357-365. Praeger, New York (1980)

Schein, E.: Career anchors: discovering your real values. Pfeiffer \& Company, San Diego, CA (1990)

Seibert, S.E., Kraimer, M.L.: The five-factor model of personality and career success. J. Vocat. Behav. 58(1), 1-21 (2001)

Thorngate, W.: "In general" vs. "it depends": some comments of the Gergen-Schlenker debate. Pers. Soc. Psychol. Bull. 2(2), 404-410 (1976)

Hugh Gunz has PhDs in Chemistry and Organizational Behaviour, is Professor of Organizational Behaviour at the Rotman School of Management, University of Toronto and Chair of the Department of Management at the University of Toronto Mississauga. He has published papers on the careers of managers, professionals and others, the management of technical professionals, and management education, is the author of the book "Careers and Corporate Cultures" (1989), and the co-editor of the "Handbook of Career Studies" (2007). He has served on the editorial boards of a number of journals, including the "Academy of Management Journal", "Journal of Managerial Psychology", and "Emergence".

e-mail: hugh.gunz@utoronto.ca

Wolfgang Mayrhofer is professor of business administration and holds a chair for management and organizational behaviour at WU Vienna, Austria. Previously, he held teaching and research positions at German universities. His research interests focus on international comparative research in human resource management, leadership and careers. He has co-edited, authored and co-authored 24 books and more than 150 book chapters and peer-reviewed articles. He regular conducts training for both public and private organizations, especially in the area of outdoor training (www.championSHIPs.at).

e-mail: wolfgang.mayrhofer@wu.ac.at 